DOI: 10.19195/0137-1150.167.21

\title{
BORIS LANIN
}

Институт стратегии развития образования Российской академии образования, Rosja

\section{Смерть и власть в литературной антиутопии}

Бытует представление, что литературная антиутопия — реакция на политические изменения, на очередные ,заморозки”, сменяющие редкие и слабые „оттепели”: „Жанр антиутопии [...] является своеобразным откликом на давление нового порядка. Антиутопия, как правило, становится ведущим жанром именно на сломе времен, в переходную эпоху"1. Однако история русской литературы последней четверти века показывает, что антиутопия - это ищущий собственную литературную идентичность жанр. Произведения этого жанра объединяют два столпа: смерть и власть. Антиутопический герой страдает от власти, борется с ней и всегда подвержен угрозе смерти. Шведский исследователь Маттиас Огрен утверждает:

The development of the Russian anti-utopian novel during the past two decades can be seen as a direct response to changes in Russian society. Literature has thus been a tool for dealing with the problems of transition in the post-Cold War world. In this process, I would contend, the key word is disillusionment ${ }^{2}$.

Конечно, родоначальником антиутопии в XX веке справедливо считается Евгений Замятин. Образы смерти, показанные им в романе, самая философия смерти стала очевидно жанровой константой. Уже в самом начале $\mathrm{XX}$ века Замятин сознательно выбирает ориентацию на чисто художественное, „технологическое” новаторство. Как ни странно, его апелляции к революции и проклятия в адрес „энтропии”, ставшей для писателя символом стагнации, носят, по сути, сугубо формальный характер. В них выражена

${ }^{1}$ И. В. Свиридов, О чем предупреждает современная антиутопия? (на примере романа Т. Толстой „Кысь”), [в:] Молодежь и наука: сборник материалов VII Всероссийской научно-технической конференции студентов, аспирантов и молодых ученых, посвященной 50-летию первого полета человека в космос, отв. ред. О. А. Краев, Красноярск 2011, http:// conf.sfu-kras.ru/sites/mn2011/section15.html [дата обращения: 28.02.2018].

${ }^{2}$ M. Agren, Phantoms of a Future Past, Stockholm 2014, c. 150. 
не его философия жизни, но философия творчества. ,Энтропия” и „,революция" — важнейшие для Евгения Замятина два состояния общества.

Был ли писатель философом? В дореволюционных произведениях Замятина не просматривается последовательная философская позиция, пожалуй, кроме случайного руссоистского стремления к „неиспорченной первозданности". Однако произведения, созданные в 20-х годах, позволяют говорить о нем как о самобытном писателе-философе. Это подтверждают Огни святого Доминика (1921), История о самой важной вещзи (1924), посмертно опубликованный Бич Божий (1935), и, конечно, роман Mbl (1920).

Возможно, под влиянием полемически настроенного окружения того периода Замятин задумал ясное философское изложение своей позиции в страстных речах героини $M b l$ I-330. Причем в своем обращении к этой проблематике Замятин не был одинок. Если им „под энтропией разумеется стремление мировой энергии к покою - к смерти”, то Николай Бердяев утверждал:

Энтропия, связанная со вторым законом термодинамики, радиоактивность и распадение атомов материи, закон относительности - все это колеблет прочность и незыблемость физико-математического миросозерцания. Я бы сказал, что все это физический апокалипсис, учение о неизбежности физического конца мира, смерти мира. [...] И не есть ли стремление к равенству в мире социальном та же энтропия, та же гибель социального космоса и культуры в равномерном распределении тепловой энергии, необратимой в энергию, творящую культуру ${ }^{3}$.

Однако для Замятина, современника Бердяева, энтропия - один из важнейших законов жизни, имеющий отношение также и к искусству. В 1923 году он писал:

Десятки имен, заглавий, бессонных ночей, достижений, ошибок, лжей и правд. Но это и есть жизнь: по безошибочным прямым, по циркульным кругам - движутся мертвые механизмы. В искусстве вернейший способ убить - это канонизировать одну какую-то форму и одну философию: канонизированное очень быстро гибнет от ожирения, от энтропии. Такая энтропия грозила за последние годы русской литературе, но живучесть ее оказалась сильнее; в литературе есть еще жизнь-борьба, пока искусственно сведенная к борьбе формальных течений ${ }^{4}$.

После написания романа $M b l$ у Замятина начались неприятности на Родине, которые привели через несколько лет к эмиграции. Литературная судьба произведения складывалась тяжело прежде всего потому, что в нем увидели пародию на революционные идеалы, ерническим тоном написанный памфлет. В этом романе действие происходит в Едином Государстве. Оно возникло после колоссальной катастрофы - Великой Двухсотлетней войны, когда уцелела лишь крохотная часть населения, меньше одного процента. Государство окружено Зеленой Стеной, за которую нельзя выходить.

${ }^{3}$ Н. Бердяев, Предсмертные мысли Фауста, [в:] Н. А. Бердяев, Я. М. Букшпан, Ф. А. Степун, С. А. Франк, Освальд Шиенглер и закат Европь, Москва 1922, с. 70-71.

${ }^{4}$ Е. Замятин, Новая русская проза, „Литературное обозрение” 1988, № 2, с. 106. 
Люди утратили имена и называют друг друга „нумерами”. Они одинаково одеты, гуляют строем под маршевую музыку, живут в стеклянных домах, чтобы легче было за ними наблюдать. Все общество под руководством Благодетеля занято строительством Интеграла. Таким образом, перед нами типичная жанровая модель литературной антиутопии. К ее особенностям можно отнести композицию: она состоит из дневниковых записей, которые главные герой пишет „для предков” — а не для потомков, как обычно принято в дневниках.

Как известно, на автомобильных заводах Форда была достигнута конвейерная автоматизация производства. Вдоль конвейера были поставлены люди, которые изо дня в день были заняты только одной технологической операцией. Это приводило их в состояние отупления, к полному эмоциональному опустошению. Такая технология превращала людей в „нумеров”, о которых и пишет Замятин в романе.

В первые годы после революции и в первой половине 20-х годов бурно обсуждалось обещанное „светлое будущее” и его основные характеристики. У захвативших власть большевиков конкретных образов будущего не было. Их „государственное строительство” даже не было утопическим: оно сводилось к удержанию власти и демагогической пропаганде, позволяющей расправляться с политическими конкурентами. Если отбросить эпитеты, то становится ясно, что никто не знал, как же конкретно это будущее выглядит. Большинство утопических и фантастических произведений той поры лишь иллюстрировали разные „уравнительные идеи”. Их было достаточно в различных марксистских журналах, и они часто излагались в примитивном популярном варианте (,для широкого читателя”). Роман $M b l$ показывал один из возможных вариантов этого будущего.

У Замятина Единое Государство подавляет индивидуальную свободу. R-13, один из рупоров государственной власти, настаивает на прямом выборе между свободой и счастьем. Он утверждает, что стремление к свободе инспирировано дьяволом.

В Едином Государстве музыка сочиняется на фабриках, а единственный поэт - государственный поэт. Счастливо регламентированные и „дозированные” граждане не в состоянии создать истинное искусство. Ведь искусство - дитя революции, и творят его не рабы-исполнители, а мечтатели и еретики. В государстве победившей утопии нет всему этому места, и оно концентрирует свою атаку на воображение - источник художественного вдохновения. При отсутствии искусства в Едином Государстве отсутствуют истина и ощущение высокой цели: больше нет честной оценки происходящих событий, нет проницательности относительно будущего.

Все это объясняет и концепцию тоталитарного искусства, которую развивает замятинский персонаж Д-503 в 12-ой записи: 
Я думал: как могло случиться, что древним не бросалась в глаза вся нелепость их литературы и поэзии. Огромнейшая великолепная сила художественного слова - тратилась совершенно зря. Просто смешно: всякий писал - о чем ему вздумается. Так же смешно и нелепо, как то, что море у древних круглые сутки тупо билось о берег, и заключенные в волнах миллионы килограммометров - уходили только на подогревание чувств у влюбленных. Мы из влюбленного шепота волн - добыли электричество, из брызжущего бешеной пеной зверя - мы сделали домашнее животное; и точно так же у нас приручена и оседлана, когда-то дикая, стихия поэзии. Теперь поэзия - уже не беспардонный соловьиный свист: поэзия - государственная служба, поэзия — полезность 5 .

Восставшие против Единого Государства нумера - это вечные еретики, для них слова „жизнь” и „перемены” - синонимы. Во имя жизни и свободы они превозносят неизвестное, иррациональное, непредвиденное и отказываются принять неизменность существующего порядка. Их название - Мефи - производное от Мефистофеля. Они утверждают, что в обществе, в самой истории революция неизбежна, ибо вечно статичное состояние невозможно.

Обратим внимание на то, что Д-503 постоянно называет себя и нумеров богами, например, в записи 12-й: „Наши боги - здесь, внизу, с нами - в Бюpo, в кухне, в мастерской, в уборной; боги стали, как мы: эрго - мы стали, как боги. И к вам, неведомые мои планетные читатели, к вам мы придем, чтобы сделать вашу жизнь божественно-разумной и точной, как наша..."”.

Конечно, для нумеров Благодетель - божество, но божество не только казнящее, палачествующее, но и скорбящее и радеющее за свой народ. Кровавые ритуалы обставляются с особой церемонностью и пышностью. Благодетель по-своему интерпретирует понятие рая:

Я спрашиваю: о чем люди - с самых пеленок - молились, мечтали, мучились? О том, чтобы кто-нибудь раз навсегда сказал им, что такое счастье, и потом приковал их к этому счастью на цепь. Что же другое мы теперь делаем, как не это? Древняя мечта о рае... Вспомните: в раю уже не знают жалости, не знают любви, там - блаженные, с оперированной фантазией (только потому и блаженные) - ангелы, рабы Божьи...

Как мы видим, важная роль в романе отводится библейским мотивам. Так, День Единогласия - выборы — названы Пасхой (явное кощунство, подмена духовного праздника бюрократическим торжеством). Самому Д-503 - тридцать два года, он как бы не доживает одного года до возраста Христа, а вот имя-номер его возлюбленной начинается с той самой недостающей единицы (или английской буквы $a \breve{u})$, за которой следует 33 . Он

${ }^{5}$ Е. Замятин, $M b l$, https://www.livelib.ru/book/121839/read-my-evgenij-zamyatin [дата обращения: 28.02.2018].

6 Там же.

7 Там же. 
не дорастает до права пострадать за людей, вынести все муки ради веры в справедливость и в необходимость лучшей жизни.

Если в начале романа, глядя в зеркало, он видит крест на своем лбу, то затем он дважды увидит крест на лице I-330, которая и заканчивает свой жизненный путь восхождением на Голгофу. Ее крест, ее распятие - это „цивилизованная” Машина Благодетеля, усовершенствованная гильотина.

Единое Государство занято не только богостроительством, но и вполне конкретной созидательной работой: строительством космического корабля Интеграл. Уже указывалось, что Д-503 гордится своей работой, быть строителем Интеграла - престижно среди нумеров. Однако диалоги между нумерами прозрачно характеризуют то, каким им видится предназначение корабля: „Я нашел, крепко сжал ее руку: — Ну что же? Что же будет? - Не знаю. Ты понимаешь, как это чудесно: не зная — лететь - все равно куда... И вот уже скоро 12 - и неизвестно что?"8.

Ни нумера, ни революционеры-Мефи не понимают, для чего же нужен Интеграл. У них есть лишь вера в его могущество. При испытаниях Интеграла гибнет десяток нумеров:

При первом ходе (=выстреле) под дулом двигателя оказался с десяток зазевавшихся нумеров из нашего эллинга - от них ровно ничего не осталось, кроме каких-то крошек и сажи. С гордостью записываю здесь, что ритм нашей работы не споткнулся от этого ни на секунду, никто не вздрогнул; и мы, и наши станки - продолжали свое прямолинейное и круговое движение с той же точностью, как будто бы ничего не случилось. Десять нумеров - это едва ли одна стомиллионная часть массы Единого Государства, при практических расчетах - это бесконечно малая третьего порядка. Арифметически безграмотную жалость знали только древние: нам она смешна 9 .

Мы можем предположить, что Интеграл нужен для переделки „космического” уклада. Однако есть человек, который должен знать конкретное его назначение. Этот человек - Благодетель. Он, сумевший подчинить своей воле Единое Государство, опутавший его „тенетами счастья”, не может остановиться в проявлениях своей власти. История Единого Государства переживает кризис, зреет революция.

Палаческие функции не единственные в биографии Благодетеля, персонажа, в образе которого сходятся многие мотивы романа. Ведь не случайно он так назван. В чем же его благодеяние? Он совершил его, встав во главе Государства и сделав его Единым. Он воплотил утопию. И его трансформация теперь неизбежна: его созидательная функция трансформируется в функцию карательную и охранительную.

Благодетель прошел это превращение. Более того, со стороны он кажется и смешным, и жалким, и мелочным, и примитивным. Восторженное

8 Там же.
9 Там же.

Slavica Wratislaviensia 167, 2018

(C) for this edition by CNS 
отношение к нему - нарочито-искусственное, привычно-ритуальное. Но мы встречаемся с ним, когда затея с Интегралом еще далека до завершения.

„Проинтегрировать” вселенную, переделать основы ее бытия пока не удалось. Утопия достигла лишь какого-то промежуточного этапа, первой стадии обязательного счастья. В беседе с Д-503 Благодетель говорит, что всему мешает фантазия, душа. И общество нашло возможность отделить душу от тела в результате Великой Операции. Сначала призываются добровольцы, затем добровольность сменяется принудительностью.

Никто не помнит благодеяний Благодетеля. Зато пытает и казнит он собственноручно и публично. Сцена пытки воспринимается героем как бы отстраненно. С душой ушла и фантазия, ушла и память, ушло прошлое, осталась лишь идиотская неизлечимая улыбка. Нумера уверяют сами себя в том, что им удалось переделать человеческую природу, что они стали богами и победили смерть, поэтому роман освобожден от трупов. Что остается от нумеров?

И, колеблемый невидимым ветром, - преступник идет, медленно, ступень еще - и вот шаг, последний в его жизни — и он лицом к небу, с запрокинутой назад головой — на последнем своем ложе.

Тяжкий, каменный, как судьба, Благодетель обошел Машину кругом, положил на рычаг огромную руку... Ни шороха, ни дыхания: все глаза - на этой руке. Какой это, должно быть, огненный, захватывающий вихрь - быть орудием, быть равнодействующей сотен тысяч вольт. Какой великий удел!

Неизмеримая секунда. Рука, включающая ток, опустилась. Сверкнуло нестерпимо острое лезвие луча - как дрожь, еле слышный треск в трубках Машины. Распростертое тело - растворяется с ужасающей быстротой. И - ничего: только лужа химически чистой воды, еще минуту назад буйно и красно бившая в сердце...

Все это было просто, все это знал каждый из нас: да, диссоциация материи, да, расщепление атомов человеческого тела. И тем не менее это всякий раз было — как чудо, это было — как знамение нечеловеческой мощи Благодетеля ${ }^{10}$.

„Химически чистая вода” — знак безгрешности. „Мыслепреступник” успел приготовиться к смерти, он „очистился”. Душа его кротко, без мучений покидает бренную телесную оболочку.

Как мы увидим, эта визуализация смерти практически полностью заимствована Владимиром Маканиным и реализована в его повести Лаз (1991). Действительно,

кажется удивительным, что Замятин, на глазах которого система ложных представлений только начинала завоевывать массы, смог предвидеть, сколь глубоким будет результат этого завоевания, какую благодатную почву найдут в человеческой психике разного рода „предрассудки” и каким мучительным будет процесс освобождения... ${ }^{11}$

10 Там же.

11 Е. Б. Скороспелова, Возвращение, [в:] Е. И. Замятин. Pro et Contra, сост. О. В. Богданова, М. Ю. Любимова, Санкт-Петербург 2014, с. 16. 
В XXI веке в контексте читательского общественного разочарования антиутопия обретает новые жанровые особенности. В романе Владимира Сорокина Манарага (2017) главный герой Геза — это продолжение Д-503. Вся его жизнь - игра со смертью. Он больше никогда не влюбляется, походная жаровня - это его личный Интеграл, изобретенный еще замятинским героем Д-503.

В антиутопиях всегда ценят специалистов. Вспомните, как ликовали Мефи, когда им объявили, что на их стороне Д-503, инженер. В конце романа, лишенный души в результате операции, Д-503 - счастлив. Этим ощущением счастья преисполнен и главный герой Манараги в конце романа: „О, этот запах счастья! О. эта нежность! Ты снова со мной. Навсегда. Навеки!"12.

Жанр по-своему решает проблему культурного пограничья. Разделительная стена между утопическим миром и миром „другим” пролегает всегда. Власть всегда настаивает на том, чтобы границы были прочерчены весьма четко. Это одна из важнейших систем ограничения персонажей. Вообще, ограничения проверяются прежде всего на протагонисте: другие персонажи антиутопических произведений попросту не замечают границ, установленных властью: они воспринимают их органично.

Ясно, что антиутопия стремится убежать, скрыться от обыденной жизни. На каких основаниях устроена новая, предлагаемая ею реальность? Ведь она не может существовать вне времени и пространства. Если сравнивать с традиционной утопией, то пространство утопии полностью иллюстративно. Оно раскладывается подобно детской книжке — ,раскладушке”. Путь утопического героя - это прогулка по райскому саду, ознакомление с новыми видами растительной жизни. Путь антиутопического героя — это балансирование между жизнью и смертью.

В Приглашении на казнь (1938) Владимира Набокова главный герой Цинциннат Ц. не может передвигаться в пространстве. Движение на плоскости ему никак не дается. Даже когда размыкаются стены камеры, и в дверной проем пролезает его обреченное тело, оказывается, что движение вперед, движение по плоскости для него бессмысленно. Он непременно возвращается в точку, из которой ушел. Он вновь возвращается на границу между жизнью и смертью, между телесной, временной, и вечной духовной жизнью.

Игрушечность жизни оказывается жестоким обманом. Воплощение власти - Мсье Пьер - оказывается одновременно и жертвой и жертворастерзателем. Дионисийская стихия торжествует здесь, как и в романе Замятина $\mathrm{Mbl}$. Жертва так же, как и I-330, беспрерывно меняет одежды, подспудно ощущая себя в нереальной, явно театрализованной жизни. Эта перемена одежд носит не только ритуальный смысл. Набокову удается угадать здесь важнейшую психологическую подоснову поведения современного человека, связанную с переменой облика.

12 В. Сорокин, Манарага, Москва 2017, с. 217. 
Сам же Цинциннат выбивается из ритуала, он - в нем и не в нем. Скоpeе, над ним. Однако Набоков подчеркивает, что Цинциннат над ним, даже будучи в нем. Пространство для Цинцинната открывается только вниз. Его взгляд на мир — взгляд не человека, но ангела, воспарившей души:

Наши путешественники очутились на широкой башенной террасе, откуда открывался вид на расстояние, дух захватывающее, ибо не только башня была громадна, но вообще вся крепость громадно высилась на громадной скале, коей она казалась чудовищным порождением. Далеко внизу виднелись почти отвесные виноградники, и бланжевая дорога, виясь, спускалась к безводному руслу реки, и через выгнутый мост шел кто-то крохотный в красном, и бегущая точка перед ним была, вероятно, собака ${ }^{13}$.

Крохотный человечек и превратившаяся в точку собака - как безнадежно оторвался от них перед смертью Цинциннат, как ничтожны эти плотские существа перед вознесшейся над землей его душой.

Второй кульминацией, совпадающей с кульминацией сюжетной, стала сцена казни. Она наиболее приближена в антиутопиях к ритуалу. Подлинные мастера вносят в ритуальную структуру собственные оттенки, поэтому поучительно проследить набоковскую интерпретацию этой темы.

Сирину свойственна сознаваемая или, быть может, только переживаемая, но твердая уверенность, что мир творчества, истинный мир художника, работою образов и приемов создан из кажущихся подобий реального мира, но в действительности из совершенно иного материала, настолько иного, что переход из одного мира в другой, в каком бы направлении ни совершался, подобен смерти, - писал Владислав Ходасевич. - Он и изображается Сириным в виде смерти. Если Цинциннат умирает, переходя из творческого мира в реальный, то обратно - герой рассказа Terra incognita умирает в тот миг, когда наконец всецело погружается в мир воображения. И хотя переход совершается здесь и там в диаметрально противоположных направлениях, он одинаково изображается Сириным в виде распада декораций. Оба мира по отношению друг к другу для Сирина иллюзорны ${ }^{14}$.

Смерть в мире Набокова Ходасевичем рассматривается только в качестве „сверхпроводника” из одного мира в другой. Подобную функцию у Булгакова, скажем, выполняло зеркало. Ходасевич исходит не из жанровой специфики, а из собственной общей концепции набоковского творчества.

Его произведения населены не только действующими лицами, но и бесчисленным множеством приемов, которые точно эльфы или гномы, снуя между персонажами, производят огромную работу: пилят, режут, приколачивают, малюют, на глазах у зрителя ставя и разбирая те декорации, в которых разыгрывается пьеса. Они строят мир произведения и сами оказываются его неустранимо важными персонажами. Сирин их потому и не прячет, что одна из главных задач его - именно показать, как живут и работают приемы.

13 В. Набоков, Приглашение на казнь, Москва 1990, с. 23.

14 В. Ходасевич, Колеблемый треножник, Москва 1991, с. 461. 
Есть у Сирина повесть, - продолжает Владислав Ходасевич, - всецело построенная на игре самочинных приемов, Приглашение на казнь есть не что иное, как цепь арабесок, узоров, образов, подчиненных не идейному, а лишь стилистическому единству (что, впрочем, и составляет одну из „идей” произведения). В Приглашении на каз$\mu b$ нет реальной жизни, как нет и реальных персонажей, за исключением Цинцинната. Все прочее - только игра декораторов-эльфов, игра приемов и образов, заполняющих творческое сознание или, лучше сказать, творческий бред Цинцинната. С окончанием их игры повесть обрывается. Цинциннат не казнен и не не-казнен, потому что на протяжении всей повести мы видим его в воображаемом мире, где никакие реальные события невозможны ${ }^{15}$.

В Приглашении на казнь мы видим, что именно мир, взявший за основу I-330, оказывается спасительным для героя. Это мир, где в системе координат, расположенной на плоскости, выстраивается перпендикуляр, выводящий всю систему в иное измерение. В момент казни Цинциннат Ц. воспаряет над плахой.

Когда Цинциннат ждет неизвестного избавителя, устраивающего подкоп под его камеру, он забывает, что его мир, — не подземный, а внеземной, мир вечной внеземной мудрости, и ему незачем ждать спасение из земного мира.

Память жанра оказывается, как обычно, едва ли не выше свидетельств „духовной близости”, к которым сам художник относился достаточно скептически. Цинциннат Ц. младше I-330, так же, как и ее возлюбленный. Он реализует в своем мире девиз Мефи, выстраивая свой мир по вертикали. Предвестник смерти - это паук, живущий в камере и появляющийся в романе несколько раз. В мире мнимого пространства стены становятся лишь декорацией:

...их было неизменно четыре; они были сплошь выкрашены в желтый цвет; но, будучи в тени, основной тон казался темно-гладким, глинчатым, что ли, по сравнению с тем переменным местом, где дневало ярко-охряное отражение окна; тут, на свету, были отчетливо заметны все пупырки густой, желтой краски, — даже волнистый заворот бороздок от дружно проехавшихся волосков кисти, - и была знакомая царапина, до которой этот драгоценный параллелограмм света доходил в десять часов утра ${ }^{16}$.

Вознесясь после смерти, Цинциннат отрывает от земли свою „материализованную духовность”. Выясняется: это был единственный источник, поддерживавший жизнь ирреальной действительности. Как в сказке Е. Шварца Тень, где, обезглавив героя, его Тень остается без головы сама, убийство Цинцинната Ц. приводит к завершению мировой истории. Совершается конец света, и о спасении задумывается даже „во много раз уменьшившийся Роман, он же Родриг"17.

Заключительная картина сродни именно апокалипсическому видению, а не только окончанию спектакля:

\footnotetext{
15 Там же, с. 461.

16 Там же, с. 67.

17 Там же, с. 129.
}

Slavica Wratislaviensia 167, 2018

(C) for this edition by CNS 
Мало что оставалось от площади. Помост давно рухнул в облаке красноватой пыли. Последней промчалась в черной шали женщина, неся на руках маленького палача, как личинку. Свалившиеся деревья лежали плашмя, без всякого рельефа, а еще оставшиеся стоять, тоже плоские, с боковой тенью по стволу для иллюзии круглоты, едва держались ветвями за рвущиеся сетки неба. Все расползалось. Все падало. Винтовой вихрь забирал и крутил пыль, тряпки, крашеные щепки, мелкие обломки позлащенного гипса, картонные кирпичи, афиши; летела сухая мгла; и Цинциннат пошел среди пыли, и падших вещей, и трепетавших полотен, направляясь в ту сторону, где, судя по голосам, стояли существа, подобные ему ${ }^{18}$.

„Приглашение” - это апофеоз несвободы, регламентация жизни по законам псевдокарнавальной репрессивной действительности. Псевдокарнавал - это игра без результата, из него можно только вырваться, что и делает в конце романа Цинциннат Ц.

Для того чтобы стать пророческой, антиутопия вовсе не должна быть эстетически совершенной или хотя бы привлекательной. Главное - разглядеть в сегодняшнем дне неожиданные ростки завтрашнего дня. В романе Виктора Пелевина S.N.U.F.F. (2011) пространство разделено на „верхний” и „нижний” миры. Верхний, шарообразный, мир - это Бизантиум, Big Byz. Нижний называется Уркаина, мир примитивный и отсталых людей. Они разделены цивилизационно, культурно и даже антропологически. Обитатели „верхнего” мира посвятили себя „маниту” — это и иносказание „монитора”, и имя верховного бога верхнего мира, и просто местная валюта, которая автоматически зачисляется на личный счет главного героя по фамилии Карпов. Девиз Карпова: „Случилось у тебя горе - продай его как радость, и будет в твоем доме счастье!”. Его работа - это продажа новостей, но если новостей нет, их нужно создать. Поэтому его видеокамера летающая, дистанционно управляемая, оснащенная пулеметом и ракетами. Если смерть не происходит, то ее следует призвать: в этом состоит, если позволить себе каламбур, призвание СМИ в Бизантиуме.

У Владимира Маканина в повести Лаз антиутопический мир на поверхности противопоставлен утопическому подземному царству изобилия и вежливости. Оставшиеся на поверхности жители могут быть убиты злобным невидимым в ночи прохожим, затоптаны стадом проносящихся по улицам соотечественников, погибнуть от нейтронного излучения, наконец, просто умереть от голода. Счастливцы находят в земле лазы - и проникают под землю, хотя бы на время: захватить обратно на поверхность необходимые предметы обихода, еду, лекарства. Главное же - мир под землей это мир легкой смерти, когда лишь пятнышко остается на асфальте - „невольная детская струйка, последнее избавление от напряжения, от обязанности жить" ${ }^{\prime 19}$. Подземелье у Маканина — вовсе не ад, а царство лег-

18 Там же, с. 130.

19 В. Маканин, Лаз, https://www.litres.ru/vladimir-makanin/laz/chitat-onlayn/ [дата обращения: 28.02.2018]. 
кой смерти. Власть исчезла из этой повести, люди оставлены наедине с неизбежной смертью.

Как известно, ,the significant number of Russian and Western scholars' texts are focused on the genesis, genre specifity, history and interconnections of utopias with other literary trends [...]"20, однако удивительным образом этот ключевой жанровый аспект остался незамеченным. А ведь антиутопии не бывает без новых святых. Именно святость придает поучительность жизни и попирает смерть. Классический пример - придуманная Уинстоном Смитом биография Огилви в романе 1984 (1949):

В трехлетнем возрасте товарищ Огилви отказался от всех игрушек, кроме барабана, автомата и вертолета. Шести лет - в виде особого исключения - был принят в разведчики; в девять стал командиром отряда. Одиннадцати лет от роду, услышав дядин разговор, уловил в нем преступные идеи и сообщил об этом в полицию мыслей. В семнадцать стал районным руководителем Молодежного антиполового союза. В девятнадцать изобрел гранату, которая была принята на вооружение министерством мира и на первом испытании уничтожила взрывом тридцать одного евразийского военнопленного. Двадцатитрехлетним погиб на войне. Летя над Индийским океаном с важными донесениями, был атакован вражескими истребителями, привязал к телу пулемет, как грузило, выпрыгнул из вертолета и вместе с донесениями и прочим ушел на дно; такой кончине, сказал Старший Брат, можно только завидовать. Старший Брат подчеркнул, что вся жизнь товарища Огилви была отмечена чистотой и целеустремленностью. Товарищ Огилви не пил и не курил, не знал иных развлечений, кроме ежедневной часовой тренировки в гимнастическом зале; считая, что женитьба и семейные заботы несовместимы с круглосуточным служением долгу, он дал обет безбрачия. Он не знал иной темы для разговора, кроме принципов ангсоца, иной цели в жизни, кроме разгрома евразийских полчищ и выявления шпионов, вредителей, мыслепреступников и прочих изменников ${ }^{21}$.

Новые святые в русской антиутопии появляются еще в Ленинграде (1924) Михаила Козырева. Здесь с церкви сняты крест и колокола, зато на иконах почему-то изображены люди в современных костюмах. Ими оказываются вожди революции. Автор вставной рукописи (как мы уже знаем, распространенный жанровый прием) сталкивается со „своей” биографией в газете:

Я с удивлением узнал, что за свой короткий век был раз двадцать ссылаем в Сибирь, что мне при каждой ссылке вырвали ноздри и ставили на лоб по клейму, что семь раз я был приговорен к повешению и даже проснулся будто бы с веревкой на шее; снимок этой веревки был помещен тут же с надписью: „Орудие убийства царских палачей”. Наконец, я был сдан насильно в рекруты и отбывал военную службу в арестантских ротах [...]. О моих личных качествах сообщались столь же невероятные вещи: оказалось, что я не умею ни читать, ни писать (царское правительство,

${ }^{20}$ M. W. Kyrchanoff, Dystopian discourse and national identity in Russian prose of the 2010s, „Toronto Slavic Quaterly” 2016, № 58, http://sites.utoronto.ca/tsq/58/Kyrchanof58.pdf [дата обращения: 20.04.2017].

21 Дж. Оруэлл, 1984 и эссе разных лет, пер. В. П. Голышев, Москва 1989, с. 48. 
как известно, не давало рабочим возможности учиться), а через две-три строки я уже оказывался редактором подпольной газеты. Дочитывая последние строки, я потерял способность смеяться ${ }^{22}$.

Очевидно, что Козырев предвосхитил появление этой жанровой черты в романе Оруэлла. Антиутопические святые всегда разрывают дистанцию между банальным и сакральным. Они травестируют подлинную святость, которая зиждется на возвышающей бессмертную душу смерти.

Антиутопическая агиография появляется в самых разнообразных жанровых разновидностях. Целиком на ней построен роман Владимира Войновича Москва 2042 (1986). Как всегда у Войновича, поэтика романа широко использует пародирование и сатирическое осмеяние. Так, в его антиутопической Москве в 2042 году оплот духовности - Коммунистическая Реформированная Церковь, почитающая святого Карла, святого Фридриха, святого Владимира, а также внесенных в святцы героев всех революций, всех войн и героев труда.

Среди новых святых в Теллурии (2013) Владимира Сорокина - Володенька, Мишенька и Вовочка, гранитные монументы которых вырублены в секретном месте:

[...] бабушка держалась молодцом, словно совсем недавно побывала здесь, как бывают православные по субботам перед Троицей на кладбищах. Она ходила вокруг изваяний, кланялась, гладила их, обкладывала их конфетами и пряниками, что, надо сказать, вовсе не выглядело смехотворным. Больше всего бабушкиного тепла и конфет досталось последнему правителю России. „Сколько же ты страданий перенес, сколько унижений, сколько осуждения и проклятий, но все стерпел, все вынес молча, милый мой, маленький мой, скромный мой...”- бормотала она, целую гранитную лысину ${ }^{23}$.

Итак, мы сконцентрировались в этой статье на литературных, эстетических константах антиутопии, оставляя за скобками ее политическую составляющую. Интенсивное развитие антиутопии в русской литературе за последние сто лет (в 2020 году мы будем отмечать столетие первого русского антиутопического романа $\mathrm{Mbl}$ ) выявило ряд факторов, сочетание которых характерно только для этого литературного жанра: пародируемый или разоблачаемый утопический проект; новая агиография; вездесущий герой Благодетель, Большой Брат; символическое представление политики; социально-сатирический илипародийныйдискурсы;,антиутопическийвирус”герой-протагонист; особые утопические границы, характерные только для пространственной антиутопической модели и т. п. К литературной антиутопии обращались Замятин и Набоков, Иван Ефремов, Аркадий и Борис Стругацкие, Войнович и Маканин, Сорокин и Пелевин, а также более тысячи писателей, чьи имена унес в небытие поток литературных публикаций.

${ }^{22}$ М. Козырев, Ленинград, [в:] его же, Пятое путешествие Гулливера, Москва 1991, c. 26 .

23 В. Сорокин, Теллурия, Москва 2013, с. 375. 
Когда утопическое „счастье для всех” начинает вызывать заслуженные сомнения, тогда и появляется антиутопический герой, и его сюжетные перипетии позволяют нам надеяться на создание еще одного антиутопического произведения, заслуживающего прочтения и сравнения с выдающимися достижениями этого жанра. Смерть в антиутопии - счастливое избавление от „всеобщего счастья”, навязанного властью.

\section{Библиография}

Бердяев Н., Предсмертные мысли Фауста, [в:] Н. А. Бердяев, Я. М. Букшпан, Ф. А. Степун, С. А. Франк, Освальд Шиенглер и закат Европь, Москва 1922, с. 70-71.

Войнович В., Москва 2042, Москва 2006.

Замятин Е., $M b l$, https://www.livelib.ru/book/121839/read-my-evgenij-zamyatin.

Замятин Е. , Новая русская проза, „Литературное обозрение” 1988, № 2, с. 106.

Козырев М., Ленинград, [в:] его же, Пятое путешествие Гулливера, Москва 1991.

Маканин В., Лаз, https://www.litres.ru/vladimir-makanin/laz/chitat-onlayn/.

Набоков В., Приглашение на казнь, Москва 1990.

Оруэлл Дж., 1984 и эссе разных лет, пер. В. П. Голышев, Москва 1989.

Пелевин В., S.N.U.F.F., Москва 2011.

Свиридов И. В., О чем предупреждает современная антиутопия? (на примере романа

T. Толстой „Кысь”), [в:] Молодежь и наука: сборник материалов VII Всероссийской научно-технической конференции студентов, аспирантов и молодых ученых, посвящеенной 50-летию первого полета человека в космос, отв. ред. О. А. Краев, Красноярск 2011, http://conf.sfu-kras.ru/sites/mn2011/section15.html.

Скороспелова Е. Б., Возвращение, [в:] Е. И. Замятин. Pro et Contra, сост. О. В. Богданова, М. Ю. Любимова, Санкт-Петербург 2014.

Сорокин В., Манарага, Москва 2017, с. 217.

Сорокин В., Теллурия, Москва 2013.

Ходасевич В., Колеблемый треножник, Москва 1991.

Agren M., Phantoms of a Future Past, Stockholm 2014.

Kyrchanoff M. W., Dystopian discourse and national identity in Russian prose of the 2010s, „Toronto Slavic Quaterly” 2016, № 58, http://sites.utoronto.ca/tsq/58/Kyrchanof58.pdf.

\section{Death and power in anti-utopian literature}

\section{Summary}

In the article, through the prism of the hero's peculiar approach to death, Russian anti-utopian literature of the twentieth and twenty-first century is discussed. The author focuses primarily on the novel by Yevgeny Zamyatin We, a short story by Vladimir Makanin Escape Hatch and the work of Vladimir Nabokov Invitation to a Beheading. The author also mentions following publications: S.N.U.F.F. of Viktor Pelevin, Leningrad of Mikhail Kozyrev as well as Moscow 2042 — anti-utopian novel by Vladimir Voinovich and Telluria, a book by Vladimir Sorokin. The researcher emphasizes that the genre structure of the plot in Russian anti-utopian literature is based on two basic pillars: death and power. Those in power manipulate subordinates by threatening them with 
death, thus maintaining society under their brutal control. Death becomes the best way to escape for the anti-utopian heroes from the "mandatory happiness for all" announced by the authorities. According to the author, the anti-utopian saints and all anti-utopian hagiography demonstrate a sarcastic approach to death and life in this type of society.

Keywords: death, power, anti-utopia, utopia, literary genre

\section{Śmierć i władza w literaturze antyutopijnej}

\section{Streszczenie}

W artykule rosyjska literatura antyutopijna XX i XXI wieku analizowana jest przez pryzmat szczególnego podejścia bohaterów do śmierci. Autor skupia się przede wszystkim na powieści Eugeniusza Zamiatina My, opowiadaniu Władimira Makanina Właz oraz dziele Vladimira Nabokova Zaproszenie na egzekucję. Wspomina również utwory: S.N.U.F.F. Wiktora Pielewina, Leningrad Michaiła Kozyriewa, powieść antyutopijną Moskwa 2042 Władimira Wojnowicza oraz książkę autorstwa Władimira Sorokina zatytułowaną Telluria. Badacz podkreśla, że główna struktura fabuły w rosyjskiej literaturze antyutopijnej opiera się na dwóch podstawowych filarach: śmierci i władzy. Posiadający władzę manipulują podwładnymi, grożąc im śmiercią, utrzymując tym samym społeczeństwo pod swoją brutalną kontrolą. Śmierć staje się jednak najlepszym sposobem ucieczki antyutopijnych bohaterów od ogłoszonego przez władze „obowiązkowego szczęścia dla wszystkich”. Według autora antyutopijni święci oraz cała antyutopijna hagiografia demonstrują sarkastyczne podejście do śmierci i życia w tego typu społeczeństwach.

Słowa kluczowe: śmierć, władza, antyutopia, utopia, gatunek literacki 